\title{
Achaete-Scute Homolog 1
}

National Cancer Institute

\section{Source}

National Cancer Institute. Achaete-Scute Homolog 1. NCI Thesaurus. Code C21321.

Achaete-scute homolog 1 (236 aa, $\sim 25 \mathrm{kDa}$ ) is encoded by the human ASCL1 gene. This protein plays a role in both transcriptional regulation and signal transduction. 